\title{
ANALISIS PREFERENSI KONSUMEN DAN STRATEGI PEMASARAN BUAH JERUK KEPROK DI KABUPATEN BOJONEGORO
}

\author{
Deviana Diah Probowati ${ }^{1}$, Suprapti Supardi ${ }^{2}$, Sri Marwanti ${ }^{3}$ \\ Program Pasca Sarjana Magister Agribisnis Universitas Sebelas Maret Surakarta \\ E-mail: devianadiahprobowati@yahoo.co.id
}

\begin{abstract}
Abstrack : This study aims to determine the factors that influence consumer preferences in purchasing fruit of tangerine, citrus fruit attributes that are preferred by consumers in choosing fruits tangerines and marketing strategies that can be applied in marketing of fruit tangerine. Factors of consumer preferences on tangerine fruit analyzed in this study were sex, education level, occupation, age, income level and number of family members or dependents in the family. The results show that factor income effect on consumer preferences tangerine fruit in Bojonegoro. While the factors gender, education, age,jobs and the number of family members does not affect the consumer's preferences tangerine fruit in Bojonegoro. Based on the analysis Fishbein of research shows that consumer attitudes to attribute more importance tangerine fruit freshness and fruit flavors tangerine which has a value of 1.72 and 0.85 respectively. Meanwhile, the price factor is not a major consideration in selecting fruit consumers tangerines. Based on these factors and attributes that influence consumers to choose fruits tangerines can be formulated alternatives marketing strategies in the fruit tangerine. Strategies that can be done is to optimize the use of seeds prefetch queue, optimizing the mutually beneficial relationship between farmers and traders, increased knowledge of farmers in the cultivation of fruits tangerines and optimize the role of the government to farmers.
\end{abstract}

Keywords: consumer preferences, marketing strategy, fruit tangerine

\begin{abstract}
Abstrak: Penelitian ini bertujuan untuk mengetahui faktor-faktor yang mempengaruhi preferensi konsumen dalam membeli buah jeruk, atribut buah jeruk yang disukai oleh konsumen dalam memilih buah jeruk dan strategi pemasaran yang dapat diterapkan dalam pemasaran jeruk buah. Faktor preferensi konsumen pada buah jeruk dianalisis dalam penelitian ini adalah jenis kelamin, tingkat pendidikan, pekerjaan, usia, tingkat pendapatan dan jumlah anggota keluarga atau tanggungan dalam keluarga. Hasil penelitian menunjukkan bahwa efek pendapatan faktor pada buah preferensi konsumen jeruk di Bojonegoro. Sedangkan faktor jenis kelamin, pendidikan, usia, pekerjaan dan jumlah anggota keluarga tidak mempengaruhi buah preferensi tangerine konsumen di Bojonegoro. Berdasarkan analisis Fishbein penelitian menunjukkan bahwa sikap konsumen untuk atribut kesegaran buah dan rasa buah jeruk yang memiliki nilai masing-masing 1,72 dan 0,85. Sementara itu, faktor harga bukan merupakan pertimbangan utama dalam memilih konsumen buah jeruk. Berdasarkan faktor-faktor dan atribut yang mempengaruhi konsumen untuk memilih buah jeruk dapat dirumuskan strategi alternatif pemasaran buah jeruk. Strategi yang dapat dilakukan adalah dengan mengoptimalkan penggunaan bibit unggul, mengoptimalkan hubungan yang saling menguntungkan antara petani dan pedagang, peningkatan pengetahuan petani dalam budidaya buah jeruk dan mengoptimalkan peran pemerintah untuk petani.
\end{abstract}

Kata kunci : preferensi konsumen, strategi pemasaran, buah jeruk keprok 


\section{PENDAHULUAN}

\section{a. Latar Belakang}

Sektor pertanian mempunyai peranan yang penting dan strategis dalam pembangunan nasional. Peranan tersebut antara lain : meningkatkan penerimaan devisa negara, penyediaan lapangan pekerjaan, perolehan nilai tambah dan daya saing, pemenuhan kebutuhan konsumsi dalam negeri, bahan baku industri dalam negeri serta optimalisasi pengelolaan sumberdaya alam berkelanjutan. Hal ini dapat ditunjukkan dengan kontribusi sektor pertanian terhadap Produk Domestik Bruto Indonesia yang menduduki peringkat ketiga dalam PDB Indonesia tahun 2015.

Sektor pertanian, kehutanan dan perikanan terbagi menjadi beberapa subsektor. Sektor pertanian terbagi menjadi beberapa subsektor yaitu subsektor pertanian, perikanan dan jasa pertanian, sub sektor kehutanan dan penebangan kayu dan subsektor perikanan.

Subsektor tanaman perkebunan menempati urutan ketiga setelah subsektor bahan makanan dan sub sektor perikanan. Hal ini menunjukkan bahwa sumbangan subsektor tanaman perkebunan terhadap pertumbuhan ekonomi masih relatif kecil dibandingkan dengan sumbangan subsektor pertanian lainnya terhadap pertumbuhan ekonomi di Indonesia.

Sektor pertanian Indonesia, masih menghadapi tantangan yang besar, terutama pada subsektor non pangan utama, seperti hortikultura dan buah-buahan, perikanan, perkebunan dan perhutanan (E. Gumbira Said dan Harist Intan, 2004:16). Persaingan yang ketat antar negara produsen komoditas komersial diduga akan semakin terjadi. Bukan mustahil, produsen komoditas pertanian Indonesia hanya akan menjadi penonton di rumahnya sendiri, menyaksikan pergulatan para produsen agribisnis dari negara lain untuk merebut pasar dalam negeri yang sangat potensial (E. Gumbira Said dan Harist Intan, 2004:16).

Buah merupakan salah satu komoditi hortikultura yang memiliki kandungan vitamin dan gizi yang sangat dibutuhkan bagi kesehatan manusia dan mudah untuk dikonsumsi.Buah dimanfaatkan untuk melengkapi kebutuhan akan tambahan variasi makanan pokok, jadi sebagai selingan dalam menu makanan. Pada masyarakat yang telah maju kebutuhan akan buah-buahan sudah merupakan kebutuhan pokok dalam menu makanan. Sehingga pada kalangan maju tersebut, buah-buahan memiliki nilai pasar yang tinggi.

Pemahaman yang mendalam mengenai konsumen akan memungkinkan pemasar atau produsen dapat mempengaruhi keputusan konsumen sehingga mau membeli apa yang ditawarkan oleh pemasar. Konsumen mempunyai perilaku pembelian kompleks jika mereka sangat terlibat dalam suatu pembelian dan menyadari adanya perbedaan signifikan antara berbagai merek (Abdullah, T, 2013: 125). Fenomena tersebut mengakibatkan konsumen mempunyai posisi tawar menawar yang kuat dan merupakan salah satu pusat perhatian pemasar dalam memasarkan produknya.

Faktor-faktor utama yang mempengaruhi perilaku konsumen menurut Kotler dan Keller (2009:166) antara lain adalah faktor budaya, faktor sosial, faktor pribadi dan faktor psikologis. Budaya merupakan salah satu penentu keinginan dan perilaku seseorang yang paling mendasar dan sesungguhnya seluruh masyarakat memiliki stratifikasi sosial dimana kelas sosial menunjukkan pilihan terhadap produk dengan merek yang berbeda-beda. Keputusan pembelian juga dipengaruhi oleh karakteristik/ ciri-ciri pribadinya, terutama yang berpengaruh adalah umur dan tahapan dalam siklus hidup pembeli, pekerjaan, keadaan sosial ekonomi, gaya hidup, pribadi dan konsep jati dirinya. Pilihan membeli seseorang juga akan dipengaruhi faktor psikologis utama yaitu motivasi, persepsi, proses belajar dan kepercayaan dengan sikap.

Dalam menghadapi era pasar bebas yang sejalan dengan masuknya buah-buahan impor, maka Indonesia harus mampu bersaing dengan mengandalkan keunggulan buah lokal spesifik. Dalam rangka meningkatkan daya saing produk pertanian khususnya buah-buahan dapat dilakukan dengan strategi pemasaran yang tepat. Strategi yang dapat diterapkan adalah strategi SWOT.

\section{b. Rumusan Masalah}

Dari uraian latar belakang diatas, maka dapat dirumuskan masalah sebagai berikut :

1. Faktor apa saja yang membedakan keputusan konsumen dalam membeli produk buah jeruk keprok 
2. Atribut-atribut apa saja yang menjadi preferensi konsumen dalam membeli produk buah jeruk keprok

3. Menganalisis strategi pemasaran yang dapat diterapkan dalampemasaran produk buah khususnya buah jeruk keprok.

\section{c. Kerangka Pendekatan Masalah}

Di era globalisasi dan pasar bebas berimplikasi berbagai jenis barang dan jasa dengan berbagai merek masuk ke pasar Indonesia. Persaingan antar merek setiap produk dari berbagai negara semakin tajam dalam merebut minat konsumen. Bagi konsumen, pasar menyediakan berbagai produk dan merek dengan banyak pilihan. Konsumen bebas memilih produk dan merek yang akan dibelinya. Keputusan membeli ada pada konsumen. Konsumen akan menggunakan berbagai kriteria dalam membeli produk dan merek tertentu. Konsumen akan membeli produk yang sesuai dengan kebutuhan, selera dan daya belinya. Konsumen tentu akan memilih produk dengan mutu yang baik dan harga yang lebih murah (Widodo, 2008:2).

Meluasnya pasar buah impor di Indonesia, karena kualitas produk buah lokal Indonesia dianggap belum bisa menunjukkan keunggulannya dibandingkan dengan buah impor dari luar.Berlakunya sistem perdagangan bebas membuat pemerintah tidak bisa berbuat banyak untuk menanggulangi terjadinya peningkatan impor buah. Hal tersebut tidak perlu terjadi jika kita bisa membuktikan bahwa produk buah Indonesia pada dasarnya sanggup bersaing dengan buah impor baik dalam kualitas maupun harga.

Sebenarnya produk buah jeruk di Indonesia mempunyai peluang untuk bersaing dengan buah jeruk impor, apalagi sentra produksi buah jeruk tersebar di seluruh propinsi

Tabel 1 . Produksi buah jeruk (ton)

\begin{tabular}{|c|c|}
\hline Tahun & Jumlah produksi (ton) \\
\hline 2010 & 2.028 .904 \\
\hline 2011 & 1.818 .949 \\
\hline 2012 & 1.611 .784 \\
\hline 2013 & 1.411 .229 \\
\hline
\end{tabular}

Sumber : BPS, 2010-2013

Tabel 2. Perkembangan produksi tanaman buah jeruk menurut jenis tanaman (ton) tahun 2011-2012.

\begin{tabular}{|c|c|c|c|c|}
\hline $\begin{array}{c}\text { Jenis } \\
\text { tanaman }\end{array}$ & $\begin{array}{c}\text { Produksi } \\
\text { thn 2011 }\end{array}$ & $\begin{array}{c}\text { Produksi } \\
\text { tahun 2012 }\end{array}$ & perkembangan & \\
\hline (ton) & (ton) & Absolut (ton) & $\%$ \\
\hline $\begin{array}{c}\text { Jeruk } \\
\text { siam/keprok }\end{array}$ & 1.711 .880 & 1.498 .396 & -223.484 & - \\
& & & & $\begin{array}{c}12,9 \\
8\end{array}$ \\
\hline Jeruk besar & 97.069 & 113.388 & 16.319 & $\begin{array}{c}16,8 \\
1\end{array}$ \\
\hline Jeruk & 1.818 .949 & 1.611 .784 & -207.165 & - \\
& & & & $\begin{array}{c}11,3 \\
9\end{array}$ \\
\hline
\end{tabular}

Sumber: BPS, 2013:73

Tabel 3. Pengeluaran rata-rata per kapita sebulan buah-buahan (rupiah)

\begin{tabular}{|c|c|}
\hline Tahun & Konsumsi \\
\hline 2010 & 12.335 \\
\hline 2011 & 12.134 \\
\hline 2012 & 15.443 \\
\hline 2013 & 16.379 \\
\hline
\end{tabular}

Sumber : BPS, 2013:57 
yang ada di Indonesia. Produksi jeruk nasional dapat dilihat pada tabel 1 dibawah ini.

Pada Tabel 1, dapat diketahui bahwa produksi buah jeruk dari tahun ke tahun mengalami penurunan. Pada tahun 2010, produksi buah jeruk sebesar 2.028.904 ton, pada tahun 2011 , produksinya turun menjadi 1.818.949 ton. Sedangkan pada tahun 2012 dan 2013 masing-masing produksinya sebesar 1.611.784 ton dan 1.411.229 ton. Menurut BPS, berdasarkan perkembangan produksi tanaman buah-buahan menurut jenis tanaman (ton) dari tahun 2011 sampai tahun 2013 dapat dilihat pada tabel 2. Menurut data BPS tahun 2013 tentang perkembangan beberapa indikator utama sosial ekonomi, konsumsi buah-buahan penduduk Indonesia berdasarkan pengeluaran rata-rata per kapita sebulan dapat dilihat pada tabel 3 .

Meskipun Indonesia berhasil menjadi salah satu produsen terbesar beberapa komoditi pertanian dunia, tetapi Indonesia belum memiliki kemampuan bersaing di pasar internasional. Selain itu, nilai tambah (value added) yang dihasilkan dari produk pertanian Indonesia dari pemanfaatan keunggulan komparatif masih relative kecil (Firdaus, 2010:15).

Dengan adanya persaingan yang ketat tentang pemasaran hasil pertanian di pasar dunia, menuntut peranan kualitas produk dan kemampuan mengantisipasi pasar (Firdaus, 2010:17). Untuk menjaga kelangsungan kemampuan menerobos pasar, kontinuitas bahan baku pertanian perlu dijamin, bukan saja dalam jumlah bahan baku yang diperlukan tetapi juga kualitas dan kontinuitasnya.

Berdasarkan uraian diatas, maka pendekatan kerangka masalah dalam penelitian ini adalah untuk mengetahui kualitas buah jeruk khususnya jeruk keprok yang diharapkan oleh konsumen melalui atribut-atribut mutu yang melekat pada buah jeruk keprok. Atribut mutu buah jeruk keprok yang dianalisis adalah harga, rasa, aroma, kesegaran, warna dan ukuran buah jeruk keprok. Dari atribut-atribut yang dianalisis dapat diketahui atribut mana saja yang menjadi pilihan utama konsumen dalam membeli buah jeruk keprok. Jika sudah diketahui atribut-atribut buah jeruk keprok dan faktor-faktor yang mempengaruhi konsumen membeli buah jeruk keprok maka dapat dianalisis strategi pemasaran yang tepat untuk meningkatkan kualitas dan pemasaran buah jeruk keprok.

\section{d. Tujuan Penelitian}

1. Mengetahui faktor-faktor yang membedakan preferensi konsumen dalam membeli produk buah jeruk keprok.

2. Mengetahui atribut-atribut yang menjadi preferensi konsumen dalam membeli produk buah jeruk keprok.

3. Menganalisis strategi pemasaran yang dapat diterapkan dalam pemasaran produk buah khususnya buah jeruk keprok.

\section{e. Manfaat Penelitian}

1. Bagi penulis, sebagai syarat untuk menyelesaikan program studi di Magister Agribisnis Universitas Sebelas Maret.

2. Bagi peneliti lain dapat digunakan sebagai tambahan referensi untuk pengembangan penelitian sejenis.

3. Bagi pemerintah dapat digunakan sebagai acuan dasar kebijakan khususnya dalam bidang hortikultura.

\section{KERANGKA BERPIKIR}

Preferensi konsumen berkaitan dengan keputusan pilihan konsumen dalam memilih atau membeli suatu produk. Preferensi konsumen juga berkaitan dengan kepuasan dalam membeli suatu produk. Preferensi konsumen dalam mengambil keputusan membeli buah lokal khususnya buah jeruk keprok dipengaruhi oleh atribut buah dan faktor-faktor konsumen dalam memilih suatu produk Atribut buah jeruk keprok yang dianalisis dalam penelitian ini adalah : (1) harga, (2) rasa, (3) warna, (4) kesegaran, (5) ukuran, dan (6) aroma.

Sedangkan faktor-faktor konsumen dalam memilih produk buah khususnya buah jeruk keprok dipengaruhi oleh berbagai macam faktor. Dalam penelitian ini, faktor-faktor yang mempengaruhi perilaku konsumen dalam membeli buah jeruk keprok dianalisis dengan menggunakan ukuran tingkat pendapatan, jenis kelamin, jenis pekerjaan, tingkat pendidikan, umur dan jumlah keluarga.

Berdasarkan atribut-atribut yang melekat pada buah jeruk keprok dapat diketahui atribut yang menjadi preferensi konsumen dalam membeli buah jeruk keprok. Berdasarkan 
atribut yang menjadi preferensi konsumen dalam membeli buah jeruk keprok dapat ditentukan strategi pemasaran yang harus dilakukan untuk meningkatkan kualitas buah jeruk keprok.

\section{METODE PENELITIAN}

\section{a. Waktu dan Tempat Penelitian}

Penelitian ini dilaksanakan secara sengaja atau purposive di Kabupaten Bojonegoro dan Kabupaten Batu Malang pada bulan Maret sampai September 2015. Sementara untuk data strategi pemasaran buah jeruk yang mendukung preferensi konsumen, peneliti mengambil sampel pedagang di Kabupaten Bojonegoro dan petani jeruk keprok di Kota Batu Malang.

\section{Metode Pengambilan Sampel}

Sampel untuk penelitian ini terdiri dari sampel konsumen, pedagang dan petani jeruk keprok. Sampel konsumen digunakan untuk menganalisis preferensi konsumen terhadap buah jeruk keprok. Sampel konsumen adalah konsumen yang berada di wilayah kota Bojonegoro. Sampel konsumen yang diambil dalam penelitian ini dilakukan secara purposive sebanyak 30 responden. Sampel pedagang dan sampel petani digunakan untuk menganalisis strategi pemasaran yang harus dilakukan untuk memasarkan buah jeruk keprok. Sampel pedagang dan petani yang diambil dalam penelitian ini masing-masing sebanyak 30 responden. Sampel pedagang diambil di wilayah Bojonegoro. Jumlah pedagang yang diambil sampelnya sebanyak 30 responden diambil secara purposive. Sedangkan sampel petani juga diambil sebanyak 30 petani. Petani jeruk yang menjadi data dalam penelitian ini adalah petani jeruk di daerah Batu Malang. Sampel petani yang diambil sebanyak 30 responden yang diambil dengan menggunakan metode snowboll sampling.

\section{Jenis dan Sumber Data \\ Data Primer}

Data primer adalah data yang langsung dan segera diperoleh dari sumber data oleh peneliti. Data primer dalam penelitian ini diperoleh langsung dari responden dengan menggunakan kuisioner yang telah dipersiapkan.

\section{Data Sekunder}

Data sekunder adalah data yang terlebih dahulu dikumpulkan dan dilaporkan oleh orang diluar peneliti. Data dicatat secara sistematis dan dikutip langsung dari instansi pemerintah atau lembaga-lembaga yang terkait dengan penelitian ini. Data sekunder diperoleh dari Badan Pusat Statistik (BPS), baik BPS Pusat maupun BPS Kabupaten Bojonegoro dan Kota Batu.

\section{b. Teknik Pengumpulan Data}

1. Observasi

Observasi adalah pengamatan langsung terhadap objek yang diteliti sehingga peneliti memperoleh gambaran yang komprehensif ( Sugiyono, 2014 : 68). Pengamatan yang dilakukan dalam penelitian ini adalah pengamatan terhadap konsumen, pedagang dan petani, sehingga peneliti tidak hanya mengumpulkan data yang kaya, tetapi juga memperoleh kesankesan pribadi dan merasakan situasi sosial yang diteliti.

2. Wawancara

Wawancara digunakan sebagai teknik pengumpulan data yang dilakukan untuk menemukan permasalahan yang diteliti dan untuk mengetahui hal-hal dari responden yang lebih dalam. Wawancara yang dilakukan dalam penelitian ini adalah wawancara kepada konsumen, pedagang dan petani.

\section{c. Metode Analisis Data}

Metode analisis data yang akan digunakan untuk perilaku konsumen adalah analisis chi squre dan model sikap fishbein. Uji chi square adalah uji statistik non parametrik yang digunakan untuk menganalisis ketidaktergantungan dan homogenitas, pada hakekatnya adalah uji keselarasan (goodness of fit test).

Rumus chi square :

$$
\mathrm{X}_{\mathrm{i}=1}^{2}=\sum^{\mathrm{k}}\left(\mathrm{O}_{\mathrm{i}}-\mathrm{E}_{\mathrm{i}}\right) / \mathrm{E}_{\mathrm{i}}
$$$$
\text { dengan derajat bebas }=\mathrm{k}-1
$$

Model sikap multiatribut Fishbein menjelaskan bahwa sikap konsumen terhadap suatu sikap (produk atau merek) sangat ditentukan sikap konsumen terhadap atribut-atribut yang 
dievaluasi. Model sikap multi atribut bermanfaat untuk mengetahui hubungan antar pengetahuan yang dimiliki konsumen tentang suatu produk dan sikap konsumen terhadap produk sesuai dengan ciri atau atribut yang dimiliki oleh suatu produk. Analisis multiatribut juga merupakan sumber informasi yang berguna bagi perencana dan tindakan pasar. Sehingga informasi yang diperoleh berguna bagi perencana dan tindakan pasar.

Model Fishbein memungkinkan pemasar mendiagnosis kekuatan dan kelemahan suatu merk produk secara relative dibandingkan dengan merk pesaing yang menentukan bagaimana konsumen mengevaluasi alternative merk produk pada atribut-atribut penting. Model Fishbein memperlihatkan bahwa sikap terhadap suatu objek tergantung probabilitas bahwa suatu objek mempunyai atribut-atribut tertentu pada tingkat yang diinginkan.

Pada model Fishbein seseorang diukur sikapnya terhadap objek tertentu berdasarkan evaluasi dan belief konsumen. Model Fishbein didasarkan pada pemikiran bahwa sikap dibentuk oleh komponen kepercayaan dan evaluasi. Model ini dapat menjelaskan dua jenis sikap berdasarkan obyek sikap yaitu sikap terhadap obyek dan sikap terhadap perilaku.

Sikap terhadap obyek

Attitude $_{0}=\Sigma b_{\mathrm{i}}$ ei

At $_{\mathrm{o}} \quad=$ sikap terhadap obyek

$\mathrm{b}_{\mathrm{i}} \quad=$ tingkat kepercayaan bahwa obyek sikap memiliki atribut tertentu

$\mathrm{e}_{\mathrm{i}} \quad=$ dimensi evaluatif terhadap atribut ke-I yang dimiliki obyek sikap

Sikap terhadap Perilaku

Attitude $_{\text {beh }}=\Sigma \mathbf{b}_{\mathrm{i}}$ ei

$\mathrm{At}_{\text {beh }}=$ sikap terhadap perilaku tertentu.

$\mathrm{B}_{\mathrm{i}} \quad=$ tingkat kepercayaan bahwa suatu perilaku akan menyebabkan hasil tertentu.

$\mathrm{E}_{\mathrm{i}} \quad=$ dimensi valuative terhadap hasil yang diperoleh

Nilai evaluasi dan kepercayaan (belief) konsumen terhadap atribut buah jeruk keprok ditentukan berdasarkan skala semantik.

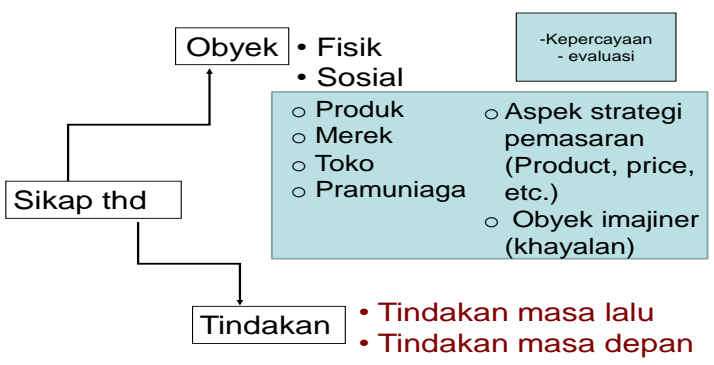

Gambar 1. Hubungan sikap dengan obyek dan tindakan

\section{d. Strategi Pemasaran}

Dari sudut pandang analisis konsumen, strategi pemasaran adalah serangkaian rangsangan ditempatkan pada lingkungan konsumen yang dirancang untuk mempengaruhi afeksi, kognisi dan perilaku konsumen. Stimulus ini melibatkan antara lain produk, label harga, komunikasi para penjual. Gambar 2 menunjukkan kerangka kerja secara lengkap yang disebut sebagai roda analisis konsumen. Bentuk roda tersebut seperti roda karena selalu berotasi secara konstan dengan perubahan pada konsumen dan strategi pemasaran. Strategi pemasaran diperlakukan sebagai poros $(h u b)$ roda karena mnerupakan pusat kegiatan pemasar dan dirancang oleh organisasi pemasaran untuk mempengaruhi perilaku konsumen.

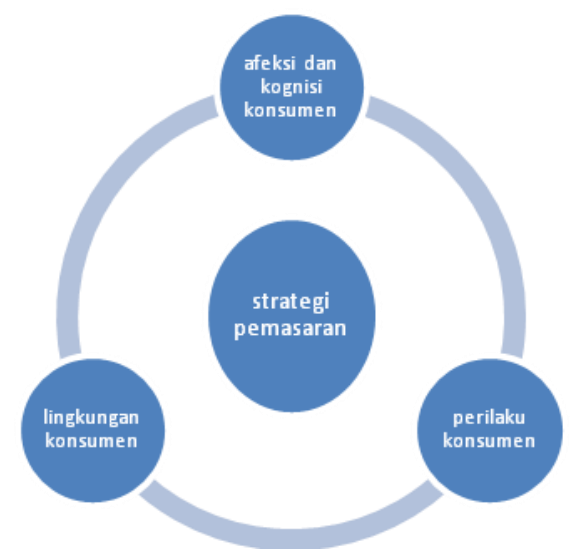

Gambar 2. Roda analisis konsumen (Peter dan Olson, $2014: 27$ )

Analisis SWOT membandingkan antara faktor eksternal peluang dan ancaman dengan faktor internal kekuatan dan kelemahan sehingga dari analisis tersebut dapat diambil suatu keputusan strategik seperti yang terlihat pada tabel di bawah ini. 
Tabel 4. Diagram matrik SWOT

\begin{tabular}{|l|l|l|}
\hline $\begin{array}{l}\text { Internal faktor(IFE)/ } \\
\text { Eksternal faktor } \\
\text { (EFE) }\end{array}$ & \multicolumn{1}{|c|}{ Kekuatan (Strenghs) } & \multicolumn{1}{c|}{ Weakness (W) } \\
\hline Opportunities(O) & $\begin{array}{l}\text { Strategi SO: } \\
\text { Menciptakan strategi yang } \\
\text { menggunakan kekuatan untuk } \\
\text { memanfaatkan peluang. }\end{array}$ & $\begin{array}{l}\text { Strategi WO : } \\
\text { Menciptakan strategi yang meminimalkan } \\
\text { kelemahan untuk memanfaatkan peluang }\end{array}$ \\
\hline Threats (T) & $\begin{array}{l}\text { Strategi ST : } \\
\text { Menciptakan strategi yang } \\
\text { menggunakan kekuatan untuk } \\
\text { mengatasi ancaman }\end{array}$ & $\begin{array}{l}\text { Strategi WT : } \\
\text { Menciptakan strategi yang meminimalkan } \\
\text { kelemahan dan menghindari ancaman }\end{array}$ \\
\hline
\end{tabular}

\section{HASIL DAN PEMBAHASAN}

\section{Preferensi Konsumen}

Dilihat dari faktor tingkat pendidikan konsumen buah jeruk keprok di Kabupaten Bojonegoro sangat beragam. Ini dapat dlihat pada tabel 5 di bawah ini.

Tabel 5. Tingkat pendidikan konsumen buah jeruk keprok di Kabupaten Bojonegoro

\begin{tabular}{|l|c|c|}
\hline $\begin{array}{c}\text { Tingkat } \\
\text { pendidikan }\end{array}$ & Responden & $\begin{array}{c}\text { Prosentase } \\
(\%)\end{array}$ \\
\hline SD / MI & 1 & 3,33 \\
\hline SMP / MTs & 1 & 3,33 \\
\hline SMA/MA/SMK & 2 & 6,67 \\
\hline SI & 22 & 73,37 \\
\hline S2 & 4 & 13,3 \\
\hline JUMLAH & 30 & 100 \\
\hline
\end{tabular}

Sumber : data primer diolah 2015

Dilihat dari faktor jenis pekerjaan, konsumen buah jeruk keprok di Kabupaten Bojonegoro sangat beragam. Ini dapat dilihat dari tabel 6 .

Tabel 6. Jenis pekerjaan konsumen buah jeruk keprok di Kabupaten Bojonegoro

\begin{tabular}{|l|c|c|}
\hline Jenis pekerjaan & Responden & $\begin{array}{c}\text { Prosentase } \\
(\%)\end{array}$ \\
\hline $\begin{array}{l}\text { Karyawan } \\
\text { Swasta }\end{array}$ & 13 & $43,34 \%$ \\
\hline Petani & 1 & $3,33 \%$ \\
\hline $\begin{array}{l}\text { Guru dan } \\
\text { pegawai pem. }\end{array}$ & 16 & $53,33 \%$ \\
\hline Jumlah & 30 & 100 \\
\hline
\end{tabular}

Sumber : data primer diolah 2015

Berdasarkan kelompok umur, konsumen buah jeruk keprok di Kabupaten Bojonegoro sangat beragam. Ini dapat dilihat pada tabel 7 .
Tabel 7. Kelompok umur konsumen buah jeruk keprok di Kabupaten Bojonegoro

\begin{tabular}{|l|c|c|}
\hline $\begin{array}{l}\text { Kelompok } \\
\text { umur }\end{array}$ & responden & Prosentase (\%) \\
\hline $20-30$ & 10 & 33.33 \\
\hline $31-40$ & 9 & 30 \\
\hline $41-50$ & 4 & 13,33 \\
\hline $51-60$ & 7 & 23,34 \\
\hline Jumlah & 30 & 100 \\
\hline
\end{tabular}

Sumber : data primer diolah 2015

Dilihat dari tingkat pendapatan, konsumen buah jeruk keprok juga beragam. Ini dapat dilihat pada tabel 8 .

Tabel 8. Tingkat pendapatan konsumen buah jeruk keprok di Kabupaten Bojonegoro

\begin{tabular}{|c|c|c|}
\hline Tingkat pendapatan & Responden & $\begin{array}{c}\text { Prosentase } \\
(\%)\end{array}$ \\
\hline$<1.000 .000$ & 9 & 30 \\
\hline $\begin{array}{c}1.000 .000 \\
2.000 .000\end{array}$ & 10 & 33,33 \\
\hline$>2.000 .000$ & 11 & 36,67 \\
\hline Jumlah & 30 & 100 \\
\hline
\end{tabular}

Sumber : data primer diolah 2015.

Berdasarkan jumlah anggota keluarga atau tanggungan dalam keluarga, hampir 90\% konsumen buah jeruk keprok di Kabupaten Bojonegoro merupakan keluarga kecil dengan jumlah anggota keluarga berjumlah 4 orang. Sedangkan, jika dilihat dari keputusan dalam membeli buah jeruk keprok lebih didominasi oleh kaum perempuan. Hal ini terlihat dari responden buah jeruk keprok di kabupaten Bojonegoro hampir $90 \%$ adalah perempuan. 
Tabel 9. Nilai chi square faktor-faktor yang membedakan preferensi konsumen buah jeruk keprok di Kabupaten Bojonegoro.

\begin{tabular}{|l|l|c|c|c|}
\hline Faktor preferensi konsumen & df & Asymp siq & Chi square hitung & Chi square tabel $(\alpha=0,05)$ \\
\hline Jenis kelamin & 1 & 0,283 & 1,154 & 3,841 \\
\hline Umur & 3 & 0,173 & 4,978 & 7,81 \\
\hline Pendidikan & 4 & 0,186 & 6,182 & 9,49 \\
\hline Pekerjaan & 1 & 0,713 & 0,136 & 3,84 \\
\hline Pendapatan & 2 & 0,022 & 7,632 & 5,99 \\
\hline Jumlah anggota keluarga & 1 & 0,361 & 0,833 & 3,84 \\
\hline
\end{tabular}

Sumber : data diolah, 2015

Tabel 10. Faktor pendapatan berbeda terhadap preferensi konsumen buah jeruk keprok.

\begin{tabular}{|c|l|l|l|}
\hline Pendapatan & preferensi & & Total \\
\hline & Tidak suka & suka & \\
\hline 1.000 .000 & 7 & 2 & 9 \\
\hline $1.000 .000-2.000 .000$ & 6 & 4 & 10 \\
\hline$>2.000 .000$ & 2 & 9 & 11 \\
\hline & 15 & 15 & 30 \\
\hline
\end{tabular}

Sumber : data diolah, 2015

Berdasarkan tabel 9, faktor pendapatan berbeda (terdapat keselarasan) terhadap preferensi konsumen buah jeruk keprok di Kabupaten Bojonegoro. Ini terlihat dari nilai chi square hitung sebesar 7,632 ynag lebih besar dari nilai chi square tabel pada taraf kepercayaan 95\% sebesar 5,99. Faktor pendapatan berbeda dalam preferensi konsumen buah jeruk keprok di Kabupaten Bojonegoro karena harga buah jeruk keprok termasuk dalam atribut yang dipertimbangkan oleh konsumen dalam membeli buah jeruk keprok. Sedangkan faktor umur, jenis kelamin, pekerjaan, pndidikan dan jumlah anggota keluarga tidak berbeda dalam preferensi konsumen buah jeruk keprok.

Berdasarkan hasil uji chi square faktor pendapatan berbeda terhadap preferensi konsumen buah jeruk keprok. Hal ini dapat ditunjukkan pada tabel 10. Berdasarkan tabel 10 dapat diketahui bahwa konsumen yang suka buah jeruk keprok lebih banyak yang pendapatannya diatas Rp. 2.000.000/bulan. Sementara konsumen yang tidak suka buah jeruk keprok adalah konsumen yang pendapatan per bulan kurang dari Rp. 1.000.000. Hal ini menunjukkan bahwa preferensi konsumen dibatasi oleh batasan anggaran atau pendapatan dan pilihan konsumen atas produk buah jeruk keprok.

Berdasarkan hasil analisis Fishbein diperoleh nilai evaluasi dan kepercayaan konsumen terhadap atribut buah jeruk keprokpada tabel 11 dan tabel 12.

Tabel 11. Nilai kepercayaan (belief) konsumen terhadap atribut buah jeruk keprok

\begin{tabular}{|l|c|}
\hline $\begin{array}{l}\text { Atribut buah jeruk } \\
\text { keprok }\end{array}$ & $\begin{array}{c}\text { Nilai evaluasi } \\
\text { kepercayaan (bi) }\end{array}$ \\
\hline Kesegaran & 1,0333 \\
\hline Warna & 0,7666 \\
\hline Aroma & 0,6667 \\
\hline Ukuran & 0,5666 \\
\hline Rasa & 0,5333 \\
\hline Harga & 0,16667 \\
\hline
\end{tabular}

Sumber : data primer diolah 2015

Dilihat dari nilai kepercayaan konsumen buah jeruk keprok terhadap atribut buah jeruk keprok menunjukkan bahwa keyakinan tertinggi konsumen terhadap atribut buah jeruk keprok dilihat dari kesegaran buah jeruk keprok yang memiliki nilai 1,0333 . Sementara atribut harga memiliki nilai kepercayaan paling rendah diantara atribut buah jeruk keprok yang lain yaitu memiliki nilai kepercayaan sebesar 0,16667 .

Berdasarkan nilai evaluasi konsumen terhadap atribut buah jeruk keprok dapat dilihat pada tabel 12 . 
Tabel 12. Nilai evaluasi konsumen terhadap atribut buah jeruk keprok

\begin{tabular}{|l|l|}
\hline Atribut & Nilai evaluasi \\
\hline Kesegaran & 1,6667 \\
\hline Rasa & 1,6 \\
\hline Aroma & 0,7333 \\
\hline Ukuran & 0,6 \\
\hline Warna & 0,6 \\
\hline Harga & 0,5333 \\
\hline
\end{tabular}

Sumber : data diolah, 2015

Berdasarkan nilai evaluasi konsumen terhadap atribut buah jeruk keprok, konsumen lebih mementingkan kesegaran dan rasa buah jeruk keprok sebagai pertimbangan utama sebelum membeli buah jeruk keprok. Hal ini terlihat dari nilai evaluasi kesegaran dan rasa yang memiliki nilai masing-masing 1,6667 dan 1,6.

Dilihat dari nilai sikap konsumen $\left(\mathrm{At}_{0}\right)$ berdasarkan analisis Fishbein, pilihan konsumen dalam membeli buah jeruk keprok dapat dilihat pada tabel di bawah ini.

Dillihat dari preferensi konsumen buah jeruk keprok dalam memilih buah jeruk keprok dapat diketahui bahwa pilihan utama konsumen dalam membeli buah jeruk keprok yaitu kesegaran buah dan rasa. Sedangkan atribut harga bukan sebagai pertimbangan utama konsumen dalam membeli buah jeruk keprok. Hal ini terjadi karena faktor-faktor yang membedakan konsumen dalam membeli buah jeruk keprok berbeda terhadap keputusan konsumen dalam membeli buah jeruk keprok. Konsumen buah jeruk keprok yang sebagian besar kaum ibu, bekerja di luar rumah, tingkat pendidikan yang tinggi lebih mengutamakan mutu/kualitas buah sebagai konsumsi dalam keluarga. Konsumen beranggapan bahwa mutu/kualitas buah dapat dilihat dari kesegaran buah yang dikonsumsi.

Tabel 13. Nilai sikap konsumen $\left(\mathrm{At}_{0}\right)$ atribut buah jeruk keprok di Kabupaten Bojonegoro

\begin{tabular}{|l|c|}
\hline Atribut & Nilai sikap konsumen \\
\hline Harga & 0,08 \\
\hline Warna & 0,46 \\
\hline Rasa & 0,85 \\
\hline Ukuran & 0,34 \\
\hline Kesegaran & 1,72 \\
\hline Aroma & 0,49 \\
\hline
\end{tabular}

Sumber : data primer diolah, 2015.

\section{B. Strategi Pemasaran Buah Jeruk Keprok}

Strategi pemasaran buah jeruk keprok dianalisis dengan menggunakan metode SWOT. Analisis SWOT merupakan identifikasi yang bersifat sistematis dari faktor kekuatan dan kelemahan serta peluang dan ancaman luar dan strategi yang menyajikan kombinasi terbaik diantara keempatnya

Tabel 14. Identifikasi kekuatan, kelemahan, peluang dan ancaman dalam pemasaran buah jeruk keprok di Kabupaten Bojonegoro

\begin{tabular}{|c|c|c|}
\hline Faktor internal & Kekuatan & Kelemahan \\
\hline $\begin{array}{l}\text { Fasilitas } \\
\text { pemerintah }\end{array}$ & $\begin{array}{ll}\text { - } & \text { Bantuan bibit unggul } \\
\text { - } & \text { Peran Balitjetro dan PPL dalam } \\
\text { melakukan pendampingan kepada } \\
\text { petani jeruk keprok }\end{array}$ & \\
\hline Letak geografis & $\begin{array}{l}\text { - Kondisi geografis kota Batu Malang } \\
\text { cocok untuk budidaya buah jeruk } \\
\text { keprok }\end{array}$ & \\
\hline $\begin{array}{l}\text { Sumber } \quad \text { Daya } \\
\text { Manusia }\end{array}$ & $\begin{array}{l}\text { - } \begin{array}{l}\text { Pelaku pemasaran buah jeruk keprok } \\
\text { (pedagang) mempunyai peran dalam } \\
\text { memasarkan buah jeruk keprok }\end{array} \\
\end{array}$ & $\begin{array}{ll}\text { - } & \text { SDM khususnya petani masih rendah } \\
\text { - } & \text { Petani dalam proses budidaya buah } \\
\text { jeruk keprok tidak berdasarkan SOP }\end{array}$ \\
\hline $\begin{array}{l}\text { Faktor } \\
\text { eksternal }\end{array}$ & Peluang & Ancaman \\
\hline $\begin{array}{ll}\text { Kondisi } & \text { sosial } \\
\text { ekonomi } & \end{array}$ & & Adanya buah jeruk impor \\
\hline $\begin{array}{l}\text { Teknik } \\
\text { budidaya yang } \\
\text { tepat antara lain } \\
\text { pemeliharaan }\end{array}$ & Penggunaan bibit unggul & Serangan hama dan penyakit \\
\hline
\end{tabular}




\section{Alternatif Strategi}

Untuk merumuskan alternatif strategi yang diperlukan dalam pemasaran buah jeruk keprok digunakan dengan analisis SWOT. Analisis SWOT adalah metode perencanaan strategis yang digunakan untuk mengevaluasi kekuatan, kelemahan, peluang dan ancaman dalam suatu usaha. Analisis SWOT dapat diterapkan dengan menganalisis dan memilah berbagai hal yang mempengaruhi kekuatan,kelemahan, ancaman dan peluang.

Matrik SWOT adalah aplikasi bagaimana kekuatan mampu mengambil keuntungan atau peluang yang ada, bagaimana mengatasi kelemahan yang mencegah keuntungan atau dari peluang yang ada. Selanjutnya bagaimana kekuatan mampu menghadapi ancaman yang ada dan bagaimana cara kelemahan yang mampu membuat ancaman menjadi nyata atau menciptakan sebuah ancaman baru. Matrik SWOT menghasilkan empat sel kemungkinan alternatif strategi, yaitu strategi $\mathrm{S}-\mathrm{O}$, strategi $\mathrm{W}-\mathrm{O}$, strategi $\mathrm{W}-\mathrm{T}$ dan strategi $\mathrm{S}-\mathrm{T}$.

Setelah mengidentifikasi faktor-faktor internal dan eksternal yang menjadi kekuatan dan kelemahan serta peluang dan ancaman dalam pemasaran buah jeruk keprok di Kabupaten Bojonegoro, maka diperoleh beberapa alternatif strategi yang dapat dipertimbangkan, antara lain : a) Strategi $\mathrm{S}-\mathrm{O}$

Strategi S - O atau strategi kekuatan peluang adalah strategi yang menggunakan kekuatan internal untuk memanfaatkan peluang eksternal. Alternatif strategi S-O yang dirumuskan adalah :

1. Mengoptimalkan penggunaan bibit unggul dengan memperhatikan teknis budidaya yang tepat.

2. Mengoptimalkan hubungan yang saling menguntungkan antara petani dan pedagang dalam pemasaran buah jeruk keprok.

b) Strategi $\mathrm{W}-\mathrm{O}$

Strategi W - O atau strategi kelemahan peluang adalah strategi untuk meminimalkan kelemahan yang ada untuk memanfaatkan peluang eksternal. Alternatif strategi $\mathrm{W}-\mathrm{O}$ yang dapat dirumuskan adalah :

1. Peningkatan pengetahuan petani dalam membudidayakan buah jeruk keprok

2. Pengoptimalan peran pemerintah terhadap petani.

c) Strategi $\mathrm{S}-\mathrm{T}$

Strategi $\mathrm{S}-\mathrm{T}$ atau strategi kekuatan ancaman adalah strategi untuk mengoptimalkan kekuatan internal yang dimiliki dalam menghindari ancaman.

Tabel 15. Diagram matrik SWOT

\begin{tabular}{|c|c|c|}
\hline & $\begin{array}{l}\text { Kekuatan (S) } \\
\text { 1.Bantuan bibit unggul } \\
\text { 2.Peranan Balitjetro dan PPL dalam } \\
\text { melakukan pendampingan bagi petani } \\
\text { 3.Kerjasama yang saling menguntungkan } \\
\text { antara petani dan pedagang }\end{array}$ & $\begin{array}{l}\text { Kelemahan }(\mathrm{W}) \\
\text { 1.SDM petani masih rendah } \\
\text { 2.Petani dalam budidaya jeruk tidak } \\
\text { berdasarkan SOP }\end{array}$ \\
\hline $\begin{array}{l}\text { Peluang }(\mathrm{O}) \\
\text { 1.Penggunaan } \\
\text { bibit unggul }\end{array}$ & $\begin{array}{l}\text { 1.Mengoptimalkan penggunaan bibit } \\
\text { unggul dengan memperhatikan teknis } \\
\text { budidaya yang tepat. } \\
\text { 2. mengoptimalkan hubungan yang saling } \\
\text { menguntungkan antara petani dan } \\
\text { pedagang dalam pemasaran buah jeruk } \\
\text { keprok }\end{array}$ & $\begin{array}{l}\text { 1.peningkatan pengetahuan petani dalam } \\
\text { membudidayakan buah jeruk keprok } \\
\text { 2. pengoptimalan peran pemerintah } \\
\text { terhadap petani }\end{array}$ \\
\hline $\begin{array}{l}\text { Ancaman }(\mathrm{T}) \\
\text { 1.Adanya } \\
\text { buah jeruk } \\
\text { impor } \\
\text { 2.Serangan } \\
\text { hama penyakit }\end{array}$ & $\begin{array}{l}\text { 1. Penggunaan bibit ungguk untuk } \\
\text { memperoleh kualitas buah jeruk keprok } \\
\text { yang bermutu }\end{array}$ & $\begin{array}{lcr}\text { 1. peningkatan pengetahuan } & \text { dan } \\
\text { keterampilan } & \text { petani } & \text { dalam } \\
\text { membudidayakan buah jeruk keprok } & \end{array}$ \\
\hline
\end{tabular}

Sumber : data diolah, 2015 
Alternatif strategi S- $\mathrm{T}$ yang dapat dirumuskan adalah :

1. Pengunaan bibit unggul untuk memperoleh kualitas buah jeruk keprok yang baik.

d) Strategi $\mathrm{W}-\mathrm{T}$

Strategi $\mathrm{W}-\mathrm{T}$ atau strategi kelemahan ancaman adalah strategi untuk meminimalkan kelemahan internal dan menghindari nacaman eksternal. Alternatif strategi $\mathrm{W}-\mathrm{T}$ yang dapat dirumuskan adalah :

1. Peningkatan pengetahuan dan keterampilan petani dalam membudidayakan buah jeruk keprok

\section{KESIMPULAN DAN SARAN}

\section{Kesimpulan}

Berdasarkan hasil penelitian mengenai preferensi konsumen dan strategi pemasaran buah jeruk keprok di Kabupaten Bojonegoro, dapat ditarik kesimpulan sebagai berikut :

1. Faktor yang mempunyai hubungan dengan preferensi konsumen buah jeruk keprok berdasarkan hasil analisis chi squae adalah tingkat pendapatan. Tingkat pendapatan berbeda dalam preferensi konsumen buah jeruk keprok mengingat bahwa pertimbangan konsumen dalam membeli buah jeruk keprok salah satu diantaranya adalah atribut harga buah jeruk keprok.

2. Preferensi konsumen dilihat dari atribut buah jeruk keprok yang menjadi pilihan konsumen dalam membeli buah jeruk keprok lebih mementingkan kesegaran dan rasa buah jeruk keprok. Hal ini terlihat dari nilai analisis Fishbein terhadap atribut kesegaran dan rasa yang lebih tinggi diantara atribut yang lain.

3. Alternatif strategi yang harus dilakukan dalam memasarkan buah jeruk keprok adalah dengan pengoptimalan penggunaan bibit unggul yang disertai dengan teknik budidaya yang baik untuk meningkatkan buah jeuk keprok agar mampu bersaing dengan buah jeuk impor. Selain itu juga perlu adanya kerjasama yang baik antara pedagang, petani dan pemerintah dalam proses pemasaran maupun budidaya buah jeruk keprok.

\section{Saran}

Berdasarkan hasil penelitian, maka saran yang dapat diberikan adalah sebagai berikut :

1. Peningkatan kualitas buah jeruk keprok dengan teknik budidaya yang tepat. Petani dalam melaksanakan proses budidaya buah jeruk keprok menggunakan bibit unggul. Penggunaan bibit unggul dengan didukung oleh teknik budidaya yang tepat dan sesuai dengan standart operasional yang sesuai dengan kondisi geografis tempat pertumbuhan buah jeruk keprok akan menghasilkan buah jeruk keprok dengan kualitas unggul. Selain itu juga harus diimbangi dengan teknik pemeliharaan dan pasca panen yang tepat. Buah jeruk keprok akan berbuah dengan baik jika dalam penyemprotan tidak mengalami keterlambatan penyemprotan. Dan cara panen yang tepat, membuat buah jeruk keprok tahan lama dalam proses penyimpanan (buha tidak mudah rusak).

2. Adanya kerjasama yang baik antara petani, pedagang dan pemerintah baik dalam pemasaran buah jeruk keprok dan teknik budidaya buah jeruk keprok. Dalam rangka meningkatkan produksi dan produktivitas buah jeruk keprok serta distribusi dan pemasaran yang baik perlu adanya kerjasama yang saling mendukung antara petani, pedagang dan pemerintah. Petani selaku produsen penghasil buah jeruk keprok, berusaha untuk menghasilkan buah jeruk keprok dengan kualitas yang baik dan mememnuhi selera konsumen buah jeruk keprok. Pedagang selaku pemasar berusaha untuk melakukan pemasaran yang baik bagi konsumen. Sementara pemerintah, berfungsi sebagai penentu kebijakan, salah satunya untuk menjaga agar hubungan antara petani dan pedagang merupakan hubungan yang saling menguntungkan.

\section{DAFTAR PUSTAKA}

Abdullah, Thamrin. 2013. Manajemen Pemasaran. Penerbit Rajawali Pers. Jakarta.

A.M. Kiloes. 2012. Penilaian Sikap dan Persepsi Konsumen Terhadap Beberapa Atribut Produk Buah Jeruk Lokal dan Jeruk Impor Sebagai Dasar 
Peningkakatan Daya Saing Jeruk Nasional. Prosiding Seminar Pekan inovasi Teknologi Hortikultura Nasional. Penerapan Inovasi Teknologi Hortikultura Dalam Mendukung Pembangunan hortikultura Yang Berdaya Saing dan Berbasis Sumberdaya Genetik Lokal. Lembang 5 Juli 2012.

Barus, Sarjana. 2008. Analisis Sikap dan Minat Konsumen Dalam Membeli BuahBuahan di Carrefour Plaza Medan Fair Dan Supermarket Berastagi Medan. Tesis. Universitas Sumatera Utara.

Balboa, Orlando and Robert Driskill. 2007. The Time Consistent Optimal Export Policy Market Structure And Time Non Separable Preference. Asia Pacific Journal Of Accounting And Economic. 14 (2007) 293-314.

BPS, 2013. Booklet August 2013. Perkembangan Beberapa Indikator utama Sosial Ekonomi. Katalog BPS :3101015. Jakarta.

2014. BPS: Bojonegoro In Figure. Bojoengoro.

.2015, Produk Domestik Bruto Indonesia. Tahun 2010 - 2014.

Dharmanesta, Basu Swasta dan T. Hani Handoko. 2014. Manajemen Pemasaran. Analisis Perilaku Konsumen. BPFE Yogyakarta.

Firdaus, Muhammad, 2010. Manajemen Agribisnis. Editor Fatna YustiantiEdisi 1 Cetakan 3. Bumi Aksara. Jakarta.

Ginting, Nembah. 2011. Manajemen Pemasaran. Penerbit Yrama Widya. Bandung.

Hanif, Z dan Lizia Zamzani. 2012. Trend Jeruk Impor dan Posisi Indonesia Sebagai Produsen Jeruk Dunia. Balai Penelitian Tanaman Jeruk dan Buah Subtropika. Kementrian Pertanian. Jakarta.
Mangkunegara , Anwar Prabu. 2012. Perilaku Konsumen. PT Refika Aditama. Bandung.

Meringgi, Amossius. 2010. Analisis Strategi Pengembangan Agribisnis Komoditas Sayuran Di Kabupaten Poso. www/referensi agribisnis.files. diakses tanggal 12 agustus 2014.

Mezious, Rim And Fatma Besbes. 2014. The Effect of Bi-dimensionality Of The Congruity On Consumer Responses. International Journal of Management Excellent Vol 3 no 1 April 2014.

Muzdalifah. 2012. Kajian Preferensi Konsumen Terhadap Buah-Buahan lokal di Kota Banjarbaru. Jurnal Agribisnis Perdesaan volume 2 Nomor 4 Desember 2012.

Nurdin, Maryam. 2012. Faktor- Faktor yang Mempengaruhi Tingkat Preferensi Konsumen Buah Di Pasar Cibinong Kecamatan Cibinong Kabupaten Bogor. Jurnal. Vol 1 No 1 Oktober 2012 hal 8599.

Karsinah, Sudarsono, Lilik Setyobudi dan Hajrial A. 2002. Keragaman Genetik Plasma Nuftah Jeruk Berdasarkan penanda RAPD . Jurnal Bioteknologi Pertanian Vol 7 No 1 pp 8-16.

Kotler, P dan Kevin Lane Keller. 2009 Manajemen Pemasaran. Edisi Ketiga Belas. Jilid 1. Penerbit Erlangga.Jakarta.

Peter dan Olson. 2014. Perilaku Konsumen dan Strategi Pemasaran. Penerbit Salemba Empat. Jakarta.

Rachmat. 2014. Manajemen Strategik. CV Pustaka Setia. Bandung

Sa'id, E. Gumbira dan Harizt Intan. 2004. Manajemen Agribisnis. Penerbit Ghalia Indonesia. Jakarta.

Soekartawi. 1999. Agribisnis : Teori dan Aplikasinya. PT Raja Grafindo Persada. Jakarta 
Deviana D. P., Suprapti S., Sri Marwanti: Analisis Preferensi Konsumen ...

Sudiyarto dan Nupfil Hanani. 2005. Analisis Daya Saing Buah Jeruk Lokal Terhadap Buah Jeruk Impor Melalui Sikap Konsumen Terhadap Atribut Produk. Prosiding disampaikan pada seminar hortikultura tanggal 28-29 Agustus 2005 di Universitas Brawijaya Malang.

Sumarwan, U. 1999. Mencermati Pasar Agribisnis Melalui Analisis Perilaku Konsumsi dan Pembelian Buah-buahan. Majalah Agribisnis. Manajemen dan Teknologi volume 5 nomor 3 November
1999. Magister Manajemen Agribisnis. IPB

, 2004. Perilaku Konsumen. Ghalia Indonesia.

Simamora Bilson, 2004. Panduan Riset Perilaku Konsumen. PT Gramedia Pustaka.

Shinta, Agustina. 2011. Perilaku Konsumen. Universitas Brawijaya 